\title{
EGU21-7593
}

https://doi.org/10.5194/egusphere-egu21-7593

EGU General Assembly 2021

(c) Author(s) 2021. This work is distributed under

the Creative Commons Attribution 4.0 License.

\section{Paleomagnetic study in lava and volcanoclastic materials of the Late-Carboniferous-Permian Cadí basin (Central-Eastern Pyrenees)}

\author{
Ana Simon-Muzas ${ }^{1}$, Antonio M Casas-Sainz ${ }^{1}$, Ruth Soto ${ }^{2}$, Elisabet Beamud ${ }^{3}$, Belén Oliva-Urcia ${ }^{4}$, \\ Emilio L Pueyo ${ }^{2}$, and Josep Gisbert ${ }^{1}$ \\ ${ }^{1}$ Geotransfer-IUCA, Ciencias de la Tierra, Universidad de Zaragoza. 50009 Zaragoza, Spain (anasimon@unizar.es) \\ ${ }^{2}$ Instituto Geológico y Minero de España (IGME). Unidad de Zaragoza, 50006 Zaragoza, Spain \\ ${ }^{3}$ Paleomagnetic Laboratory CCiTUB - Geosciences Barcelona (Geo3Bcn), CSIC. 08028 Barcelona, Spain \\ ${ }^{4}$ Universidad Autónoma de Madrid, Spain
}

This work presents preliminary paleomagnetic results from the Cadí basin, one of the Pyrenean Late-Carboniferous-Permian basins.

These basins are the consequence of a complex tectonic evolution. At the outset, they were controlled by an extensional or transtensional regime during the progressive dismantling of the Variscan chain that gradually changed to a strike-slip fault regime. Afterwards, during Pyrenean compression (Late Cretaceous to Cenozoic) most of these basins were inverted and transported southwards as a part of the basement units. All of them are characterized by a similar subsidence pattern interpreted as graben or half-graben continental troughs. In a close relationship with its genesis, during Late-Carboniferous-Permian times, several magmatic events took place. Because of that, fluvio-lacustrine sediments present lateral changes to volcanic and volcanoclastic deposits and materials are sometimes cut by intrusions.

The studied zone, the Cadí basin, is located at the eastern Pyrenees, south of the Axial Zone, and shows a high variability of Late-Carboniferous-Permian volcanic products in E-W continuous outcrops that reach several hundred meters of thickness with a good preservation and exposition. The Late Carboniferous-Permian evolution of the Cadí basin was strongly controlled by tectonics and volcanism. In order to characterize this stage and its volcanic rocks, we applied in a previous work the anisotropy of magnetic susceptibility (AMS) technique to determine the primary magnetic fabric of lava flows and volcanoclastic materials. A dominant WNW-ESE direction of the magnetic lineation was recognized related to the paleoflow direction. Paramagnetic minerals and magnetite were recognized as the main carriers of the AMS.

In this work we present the paleomagnetic results from 15 sites (about 150 specimens) in volcanic, volcanoclastic and intrusive materials sampled along four N-S cross sections. The obtained results indicate that the carrier of the magnetization are both magnetite and haematite. The thermal demagnetization of samples shows a paleomagnetic component with unblocking temperatures from $480^{\circ} \mathrm{C}$ with reversed polarity and very low inclination after bedding correction. In some sites a normal polarity component is also recognized. These results seem to be coherent with a 
magnetization coetaneous with the emission and deposition of these materials during Permian times. In cases where the samples record a normal component is important to take into account the complex structural situation of these outcrops. 